\title{
How Women in Search of Suitable Contraceptive Methods can Remedy the Lack of Counseling and Circumvent Untrustworthy Information Disseminated by Various Media
}

\author{
Kurt Kraetschmer MD, PhD* \\ Austrian American Medical Research Institute, Austria
}

*Corresponding Author: Kurt Kraetschmer MD, PhD, Austrian American Medical Research Institute, Austria, Email: kurt.kraetschmer@aon.at

\begin{abstract}
Background: The urgent need for appropriate counseling regarding contraceptive options is a well-known phenomenon in the clinical practice. Recent events show that this need has not yet been met. On the background of this evidence, new avenues are explored to enable women to remedy the lack of adequate counseling and circumvent untrustworthy information disseminated by various media.
\end{abstract}

Material and Method: Material used comprises publications in leading medical journals with the highest impact factors, publications by manufacturers and by the internationally most influential health agencies. This material is subjected to a methodological analysis which is guided by the bioethical principles of nil nocere and informed consent.

\section{The Table below (Table 1) Displays this Synoptic Contraception Overview}

Table1: Safety-Efficacy-Satisfaction (Convenience)-Cost Ranking (SESC-Ranking)

\begin{tabular}{|c|c|c|c|c|}
\hline $\begin{array}{l}\text { Results: The result } \\
\text { of the analysis } \\
\text { performed is a } \\
\text { synoptically } \\
\text { structured overview } \\
\text { of the currently } \\
\text { available methods } \\
\text { which are ranked } \\
\text { primarily according } \\
\text { to the parameter } \\
\text { safety, but also } \\
\text { according to efficacy, } \\
\text { continuation of use, } \\
\text { i.e., satisfaction, } \\
\text { convenience, and } \\
\text { cost. }\end{array}$ & $\begin{array}{l}\text { Safety (no harm } \\
\text { in the sense of } \\
\text { "nil nocere") }\end{array}$ & $\begin{array}{l}\text { Efficacy } \\
\text { Perfect- } \\
\text { Typical use }\end{array}$ & $\begin{array}{l}\text { Satisfaction }[\% \\
\text { women } \\
\text { continuing after } \\
\text { one year] } \\
\text { Convenience }\end{array}$ & Cost \& Specifications \\
\hline \multicolumn{5}{|l|}{ Method } \\
\hline $\begin{array}{lr}\text { Symptothermal } \\
\text { (measure } & \text { body } \\
\text { temperature } & \text { and } \\
\text { observe } & \text { cervical } \\
\text { mucus) } & \end{array}$ & High & $0.4-24$ & $\begin{array}{l}? \\
\text { High }\end{array}$ & $\begin{array}{l}\text { No cost. Cervix palpated } \\
\text { has soft consistency and } \\
\text { is open. }\end{array}$ \\
\hline $\begin{array}{l}\text { Ovulation (based on } \\
\text { cervical mucus). }\end{array}$ & High & $3-24$ & $\begin{array}{l}? \\
\text { High }\end{array}$ & $\begin{array}{l}\text { No cost. Observe cervical } \\
\text { mucus ("spinnbarkeit" } \\
\text { indicates fertile period). }\end{array}$ \\
\hline $\begin{array}{lrr}\text { TwoDay } & \text { (based } & \text { on } \\
\text { cervical } & \text { mucus) } \\
\text { Fertility } & \text { not to be } \\
\text { assumed } & \text { after } & 2 \\
\end{array}$ & High & $4-24$ & $\begin{array}{l}? \\
\text { High }\end{array}$ & $\begin{array}{l}\text { No cost. Fertile days to be } \\
\text { assumed when cervical } \\
\text { mucus is present (watch } \\
\text { color and consistency). }\end{array}$ \\
\hline
\end{tabular}


How Women in Search of Suitable Contraceptive Methods can Remedy the Lack of Counseling and Circumvent Untrustworthy Information Disseminated by Various Media

\begin{tabular}{|c|c|c|c|c|}
\hline $\begin{array}{l}\text { consecutive "dry" } \\
\text { days (or absence of } \\
\text { secretion). }\end{array}$ & & & & \\
\hline $\begin{array}{l}\text { Standard } \quad \text { Days } \\
\text { Method (SDM) - } \\
\text { based on calendar (to } \\
\text { track fertile period). }\end{array}$ & High & $5-24$ & $\begin{array}{l}\text { ? } \\
\text { High }\end{array}$ & $\begin{array}{l}\text { No cost. Fertile period } \\
\text { usually days } 8-19 \text { of each } \\
26-32 \text { day cycle. }\end{array}$ \\
\hline $\begin{array}{l}\text { Basal Body } \\
\text { Temperature (BBT) } \\
\text { Fertile period has } \\
\text { passed when body } \\
\text { temperature has risen } \\
\text { (by } 0.2-0.5^{\circ} \mathrm{C} \text { ) and } \\
\text { remained such for } 3 \\
\text { days. }\end{array}$ & High & $1-25$ & $\begin{array}{l}? \\
\text { High }\end{array}$ & $\begin{array}{l}\text { No cost. Does not predict } \\
\text { end of fertile period, but } \\
\text { conception is unlikely } \\
\text { from the } 4 \text { th } \text { day } \\
\text { following rise } r \text { of } \\
\text { temperature (until next } \\
\text { period). }\end{array}$ \\
\hline $\begin{array}{l}\text { Calendar (rhythm) } \\
\text { method Monitor } \\
\text { menstrual cycle for } \\
\text { at least } 6 \text { months by } \\
\text { using calendar. }\end{array}$ & High & $9-25$ & $\begin{array}{l}\text { ? } \\
\text { High }\end{array}$ & $\begin{array}{l}\text { No cost. Check calendar } \\
\text { to find shortest cycle and } \\
\text { substract 18: this is the } \\
\text { estimated FIRST fertile } \\
\text { day. Find longest cycle } \\
\text { and substract 11: this is } \\
\text { the estimated LAST last } \\
\text { fertile day. Caution with } \\
\text { drugs such as NSAID, } \\
\text { antibiotics, anxiolytics, } \\
\text { anti-depressants, and } \\
\text { others (consult physician). }\end{array}$ \\
\hline $\begin{array}{l}\text { Withdrawal (coitus } \\
\text { INTERRUPTUS) } \\
\text { Lactational } \\
\text { Amenorrhea (LAM) } \\
\text { Requires } \\
\text { breastfeeding day } \\
\text { and night of infant } \\
\text { less than } 6 \text { months } \\
\text { old. }\end{array}$ & High High & $4-22 ?$ & $\begin{array}{l}46 \% \\
\text { High }\end{array}$ & $\begin{array}{l}\text { Semen must be } \\
\text { discharged outside the } \\
\text { vagina. Effective in } \\
\text { preventing ovulation as } \\
\text { long as monthly bleeding } \\
\text { has not yet resumed. }\end{array}$ \\
\hline $\begin{array}{l}\text { Male condoms Latex } \\
\text { allergy possible. }\end{array}$ & Moderate & $2-18 / 43 \%$ & $\begin{array}{l}43 \% \\
\text { High }\end{array}$ & $\begin{array}{l}\text { Low cost. Protects against } \\
\text { sexually transmitted } \\
\text { diseases (STD) including } \\
\text { HIV. }\end{array}$ \\
\hline $\begin{array}{l}\text { Implant (Small, } \\
\text { flexible rod or } \\
\text { capsule placed under } \\
\text { the skin of the upper } \\
\text { arm; contains } \\
\text { progestogen } \\
\text { hormone only). }\end{array}$ & $\begin{array}{l}\text { Moderate Incorrect } \\
\text { placement is } \\
\text { possible, device can } \\
\text { break or travel to } \\
\text { pulmonary artery. } \\
\text { Irregular vaginal } \\
\text { bleedings common. }\end{array}$ & $0.05-0.05$ & $\begin{array}{l}84 \% \\
\text { High }\end{array}$ & $\begin{array}{l}\text { High cost. Has to be } \\
\text { implanted by clinician. }\end{array}$ \\
\hline $\begin{array}{l}\text { Mirena } \\
\text { Intrauterine } \text { device } \\
\text { (IUD) (T-shaped } \\
\text { plastic } \\
\text { inserted into the } \\
\text { uterus; releases } \\
\text { continuously small } \\
\text { amounts } \\
\text { levonorgestrel). }\end{array}$ & $\begin{array}{l}\text { Moderate Pelvic } \\
\text { inflammatory } \\
\text { disease (PID) } \\
\text { common, ascending } \\
\text { infection and } \\
\text { expulsion possible. }\end{array}$ & $0.2-0.2$ & $\begin{array}{l}80 \% \\
\text { Moderate }\end{array}$ & $\begin{array}{l}\text { High cost. Prevents } \\
\text { contact between sperm } \\
\text { and egg by thickening } \\
\text { cervical } \\
\text { Amenorrhea common. }\end{array}$ \\
\hline $\begin{array}{l}\text { ParaGard } \quad \text { (copper } \\
\text { IUD) }\end{array}$ & Moderate & $0.6-0.8$ & $\begin{array}{l}78 \% \\
\text { Moderate }\end{array}$ & $\begin{array}{lr}\begin{array}{l}\text { High cost. } \\
\text { component }\end{array} & \text { Copper } \\
\text { damages } \\
\text { sperms. }\end{array}$ \\
\hline Depo-Provera & Moderate & $0.2-6$ & $\begin{array}{l}56 \% \\
\text { Moderate }\end{array}$ & High cost. \\
\hline
\end{tabular}


How Women in Search of Suitable Contraceptive Methods can Remedy the Lack of Counseling and Circumvent Untrustworthy Information Disseminated by Various Media

\begin{tabular}{|c|c|c|c|c|}
\hline $\begin{array}{l}\text { Combined oral } \\
\text { contraceptives } \\
(\mathrm{COCs})=\text { "the pill"" }\end{array}$ & Moderate & $0.3-9$ & $\begin{array}{l}67 \% \\
\text { Moderate }\end{array}$ & $\begin{array}{l}\text { Moderate cost. Contains } \\
\text { estrogen and progestogen. }\end{array}$ \\
\hline $\begin{array}{l}\text { Progestogen-only pill } \\
\text { (POP) or "minipill"“ }\end{array}$ & Moderate & $1-3(10)$ & $\begin{array}{l}67 \% \\
\text { Moderate }\end{array}$ & $\begin{array}{l}\text { Moderate cost. Thickens } \\
\text { cervical mucus and } \\
\text { prevents ovulation. }\end{array}$ \\
\hline Evra patch & Moderate & $0.3-9$ & $\begin{array}{l}67 \% \\
\text { Moderate }\end{array}$ & High cost. \\
\hline NuvaRing & Moderate & $0.3-9$ & $67 \%$ & High cost \\
\hline $\begin{array}{l}\text { Combined } \\
\text { contraceptive patch } \\
\text { and combined } \\
\text { contraceptive vaginal } \\
\text { ring (CVR) }\end{array}$ & Moderate & $1-8(?)$ & $\begin{array}{l}? \\
\text { Low }\end{array}$ & $\begin{array}{l}\text { High cost. Continuously } \\
\text { releases progestin and an } \\
\text { estrogen directly through } \\
\text { the skin (patch) or from } \\
\text { the ring. Pharmacokinetic } \\
\text { profile similar to COCs. } \\
\text { (Research on efficacy } \\
\text { limited). }\end{array}$ \\
\hline $\begin{array}{l}\text { Monthly injectables } \\
\text { or } \quad \text { combined } \\
\text { injectable } \\
\text { contraceptives (CIC) }\end{array}$ & $\begin{array}{l}\text { Moderate Irregular } \\
\text { vaginal bleeding }\end{array}$ & $1-3$ & $\begin{array}{l}? \\
\text { Low }\end{array}$ & $\begin{array}{l}\text { High cost. Injected } \\
\text { monthly into muscle. }\end{array}$ \\
\hline $\begin{array}{l}\text { Progestogen-only } \\
\text { injectables }\end{array}$ & $\begin{array}{l}\text { Moderate Irregular } \\
\text { vaginal bleeding; } \\
\text { delayed return to } \\
\text { fertility after use. }\end{array}$ & $1-3$ & $\begin{array}{l}? \\
\text { Low }\end{array}$ & $\begin{array}{l}\text { High cost. Injected into } \\
\text { muscle or under skin } \\
\text { every } 2 \text { to } 3 \text { months } \\
\text { (depending on product) }\end{array}$ \\
\hline $\begin{array}{l}\text { Diaphragm Must be } \\
\text { used for each coitus. }\end{array}$ & Moderate & $6-12$ & $\begin{array}{l}57 \% \\
\text { Low }\end{array}$ & High cost. \\
\hline $\begin{array}{l}\text { Emergency } \\
\text { Contraception (EC) } \\
\text { Pills ulipristal acetate } \\
30 \text { mg or } \\
\text { levonorgestrel } 1.5 \\
\text { mg should be taken } \\
\text { twice to prevent } \\
\text { pregnancy up to } 5 \\
\text { days subsequent to } \\
\text { coitus. }\end{array}$ & Moderate - Low & $1-15$ & $\begin{array}{c}? \\
\text { High }\end{array}$ & $\begin{array}{l}\text { Moderate cost. Instead of } \\
\text { pill IUD (copper or } \\
\text { levonorgestrel) can be } \\
\text { inserted. }\end{array}$ \\
\hline $\begin{array}{l}\text { Male sterilization } \\
\text { (vasectomy) }\end{array}$ & $\begin{array}{l}\text { Moderate Adverse } \\
\text { events and risks } \\
\text { associated } \\
\text { surgery. }\end{array}$ & $\begin{array}{l}<1 \text { (after 3- } \\
\text { months } \\
\text { semen } \\
\text { evaluation). } \\
2-3 \\
\text { (without } \\
\text { semen } \\
\text { evaluation). }\end{array}$ & $\begin{array}{l}100 \% \\
\text { High }\end{array}$ & $\begin{array}{l}\text { High cost. Permanent } \\
\text { contraception due to } \\
\text { cutting vas deferens tubes } \\
\text { (which transport sperm } \\
\text { from testicles). }\end{array}$ \\
\hline $\begin{array}{l}\text { Female sterilization } \\
\text { (tubal ligation) } \\
\text { Permanent } \\
\text { contraception (due to } \\
\text { blocking or cutting } \\
\text { fallopian tubes). }\end{array}$ & $\begin{array}{lr}\text { Low Adverse } \\
\text { events and } & \text { risks } \\
\text { asscoiated } & \text { with } \\
\text { surgery. } & \end{array}$ & $0.5-0.5$ & $\begin{array}{l}100 \% \\
\text { High }\end{array}$ & $\begin{array}{l}\text { High cost. Surgery } \\
\text { required. }\end{array}$ \\
\hline $\begin{array}{l}\text { Sterilization through } \\
\text { creation of scar } \\
\text { tissue (ESSURE) }\end{array}$ & Very low & $?$ & $\begin{array}{l}? \\
\text { Low }\end{array}$ & $\begin{array}{llr}\text { Device } & \text { has } & \text { been } \\
\text { withdrawn from the } \\
\text { market in several } \\
\text { countries, including the } \\
\text { U.S. }\end{array}$ \\
\hline Sponge & Moderate & 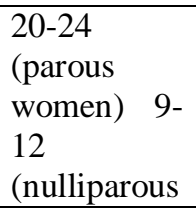 & $\begin{array}{l}36 \% \\
\text { Moderate }\end{array}$ & $\begin{array}{l}\text { Moderate cost. Must be } \\
\text { used for each coitus. }\end{array}$ \\
\hline
\end{tabular}


How Women in Search of Suitable Contraceptive Methods can Remedy the Lack of Counseling and Circumvent Untrustworthy Information Disseminated by Various Media

\begin{tabular}{|l|l|l|l|l|}
\hline & & women) & & \\
\hline Spermicides & Moderate & $18-28$ & $\begin{array}{l}42 \% \\
\text { High }\end{array}$ & Moderate cost. \\
\hline
\end{tabular}

\section{DISCUSSION}

In 2018, a spokesman of the FDA openly admitted the existence of a problem that has been plaguing the clinical practice for many years, namely lack of adequate counseling for women who are in search of the personally must suitable method for family planning, birth control or contraception. In conjunction with a device for permanent contraception which had caused severe harm to thousands of women worldwide it has been noted that women did not receive adequate counseling prior to the implementation of a contraceptive method. This lack was the more surprising as the FDA had already earlier restricted implantation of the device to those physicians who had signed a document attesting that they had provided counseling for the women receiving the device: "'Despite previous efforts to alert women to the potential complications of Essure, we know that some patients still aren't receiving this important information,' said FDA Commissioner Scott Gottlieb, in a statement. 'That is simply unacceptable.'"[1] In criticizing a serious lack of counseling, the FDA admits that patients' right of self-decision according to the principle of informed consent had been seriously violated. [2] The problem of denying the right of women to self-decision is unfortunately not a recent phenomenon, as can be seen from a study focusing on self-decision in conjunction with contraceptive methods published in Germany. [3]

The fatal consequences of the lack of counseling have been reported by news media around the world. In the US, the press drew attention to adverse events caused by the device and the ensuing legal ramifications: "It has been the subject of an estimated 16,000 lawsuits or claims filed by women who reported severe injuries, including perforation of the uterus and the fallopian tubes. Several deaths, including of a few infants, have also been attributed to the device or to complications from it. "[1]

In Australia, the Therapeutic Goods Administration (TGA) had issued a hazard alert earlier, and the company apparently felt compelled to recall its product already in 2017. According to Australian media, this alert was prompted by reports about severe harm experienced by the users: "The reports have included changes in menstrual bleeding, unintended pregnancy, chronic pain, perforation, migration of the device, and allergy/ hypersensitivity or immune-type reactions. Surgery, including hysterectomy, was required in some instances to remove the device,' the TGA said. "[4]

What came as a surprise to consumers in the US was the FDA's emphasis on the safety of the device: "Bayer announced that they will no longer sell or distribute Essure in the U.S. after December 31, 2018, for business reasons. This information does not change the FDA's understanding of the safety and effectiveness of the device ... "[1] As can be seen, the FDA insists on the safety of the device despite the harm it had caused to thousands or perhaps millions of women worldwide. In doing so, the FDA clearly neglects the well established medical principle of nil nocere which stipulates treatment of the patient without causing harm to her/his heath. The FDA's emphasis on the safety of a device that has caused serious harm brings to light also a problem that is frequently encountered in the scientific literature, namely the disregard for the parameter safety. By arguing that "the benefits outweigh the risks," the problem of safety is frequently belittled. [5] As a consequence, women recognize that they cannot count on information even if it emanates from the most influential organization. Unfortunately unreliable information disseminated by influential organization is not the only problem. An additional problem is the information provided by manufacturers on their products, a problem recently elucidated in the area of pharmaceutico-vigilance. [6] Thus in conjunction with the harmful device for permanent contraception, the National Center for Health Research criticized information provided by the manufacturer as being too long, technical and confusing: "'How many people do you know who would carefully read a 22-page document before signing it?' said Diana Zuckerman, president of the National Center for Health Research, a consumer advocacy group. 'In addition to being much too long and technical, the information provided will be confusing to many consumers."'[1]

In addition to flawed information furnished my manufacturers, there is an additional problem 
for women in search or reliable information, namely discordant statements in the scientific literature. It is particularly deplorable that it is just precisely the most effective methods of contraception, [7] namely Long-Acting Reversible contraception (LARC), on for which contradictory statements are made in the most prestigious scientific journals. One of the most striking examples of contradictory claims is evidence-based critique of traditional devices voiced by Belgian authors on the one hand, [8] and total disregard of this critique by US authors on the other.[9]

As early as 2013 Belgian authors described a new device, designated "Gynefix," which was designed to remedy the deficits of the hitherto available devices.[10] The critique of the "conventional" devices, ie, ParaGard and Mirena, approved for and distributed on the US market seems convincing as it is the result of evidence-based research on measurements of the uterine cavity and on the inappropriate dimensions of the conventional devices.[8] Interestingly enough, this critique has been neglected by the authors of one of the most pertinent publications on Long-Acting Reversible Contraception (LARC), which appeared in 2017 in one of the world's leading medical journals.[9] These authors hail LARC justifiably as the most effective methods of contraception, but ignore the evidence-based findings described in the 2013 publication. Indeed, there is no discussion of the shortcomings attributed to conventional LARCs; GyneFix is not even mentioned as one of the devices belonging to LARC; and references regarding the publications on GyneFix are untraceable. Instead, the authors of the 2017 publication hail precisely those LARC devices that have been considered inappropriate in the publication of 2013. LARCs are recommended not only by virtue of their high effectiveness and safety but also owing to their noteworthy rate of continuation. Without paying heed to the critique of the Belgian authors regarding the harmful effects of "conventional" devices, the US authors conclude: "All adolescents and adult women should be informed about the availability of LARC methods, given their extremely high effectiveness, safety, and high rate of continuation." $[9, \mathrm{p} .467]$

In the face of such discordant findings women will be reluctant to rely on recommendations made in the scientific literature. Indeed educated consumers are keenly aware of the problem of conflicts of interest which is increasingly plaguing scholarly publications.[9] Instead of impartial assessments the reader of these publications finds unverifiable statements endorsing the interests of the pharmaceutical company from which the authors receive grants, stipends, scholarships, and similar financial incentives. It should be noted in this context that authors publishing in Japanese journals undergo a more serious scrutiny concerning conflicting interests than those publishing in US-, European-, or Australasian journals.

\section{RESUltS}

As the above discussion shows, counseling for women in search of suitable methods for birth control and contraception is urgently needed especially in light of new pills and devices developed by pharmaceutical companies and available for the consumer on the market in most countries around the globe. Counseling should focus on the numerous adverse events, potential complications, and risks associated with contraceptive products. As past experience shows, serious consequences of these products have been brought to light by research in pharmacovigilance. Among these consequences are leukemia in children of mothers who have taken oral contraceptive pills,[11] depression and even suicidal action in association with certain pills for contraception,[12] the possibility of glaucoma causally related to hormonal contraception,[13] and a heightened risk of breast cancer for women taking oral contraceptives.[14] In addition a serious impact on the quality of life owing to oral contraceptive pills has been described.[15] In view of such detrimental consequences of uncritical use of contraceptive methods, physicians are challenged to pay heightened attention to appropriate counseling despite the pressure of economic maxims emphasizing such parameters as cost efficiency.[16] To facilitate their counseling obligations, suitable instruments such as the Synoptic Contraceptive Overview based on the most reliable sources, namely Contraceptive Failure Table of 2011,[17] the WHO list of 2016,[18] and the FDA survey of 2013[19] -- will prove helpful. As this instrument can be easily used by women themselves, future common pursuits to identify the personally most suitable method of contraception should be more satisfying for 
both, physicians and women, and reduce the danger of suffering harm due to the employment of inappropriate products for birth control and contraception.

\section{CONCLUSION AND IMPLICATIONS}

As the above analysis shows, women in search of the personally most suitable contraceptive method are frequently left out in the cold. They have to cope with the problem of how to obtain information that is not only accurate and complete but also trustworthy and reliable. In order to enable women to remedy the lack of counseling, autodidactic strategies are recommended based on such instruments as the Synoptic Contraception Overview (SCO). Utilization of this table not only assists women in identifying the personally most suitable method but spares also physicians the timeconsuming efforts of accessing pertinent information by means of scholarly publications or manufacturers' product descriptions.

\section{REFERENCES}

[1] Washington Post, April 11, 2018. Https://www. washingtonpost.com/.../2018/...sales-of-essurebirth.... html.

[2] Code of Medical Ethics. Current Opinions (1992) American Medical Association. Chicago, Illinois.

[3] Kraetschmer K. Are women denied the right of self-decision? Saarbrücken: Scholars' Press, 2017.

[4] The Guardian. Mon 13 Aug 201801.40 BST Last modified on Mon 13 Aug 201802.55 BST. Https://www.upi.com/.../2018/.../13/Bayer.../56 11534172665/13.08.2018.

[5] Kraetschmer K. Safety of Birth Control and Contraception: Pharmaceutical Companies on the Testing Bench. LOJ Phar \& Cli Res 1(4)2019:80-86. LOJPCR.MS.ID.000116. DOI: 10.32474/LOJPCR.2019. 01.000116.

[6] Kraetschmer K. Recent findings in pharmacovigilance and pharma ceuticovigilance. In press.

[7] Trussell J. Contraceptive efficacy. Table 3-2. In: Hatcher RA, Trussell J, Nelson AL, Cates W, Kowal D, Policar M. Contraceptive Technology: Twentieth Revised Edition. New York, NY: Ardent Media, 2011. CTFailure. Table.pdf.

[8] Wildemeersch D, Pett A, Jandi S, Hasskamp T,Rowe P, Vrijens M. Precision intrauterine contraception may significantly increase continuation of use: a review of long-term clinical experience with frameless copperreleasing intrauterine contraception devices. Int J Womens Health. 2013; 5: 215-225. Published online 2013 Apr 30. doi: 10.2147/IJWH.S42 784PMCID: PMC3645905. PMID: 23658502.

[9] Curtis KM, Peipert JF. Long-Acting Reversible Contraception. N Engl J Med 2017; 376:461-8. DOI: 10. 1056/NEJMcp1608736.

[10] GyneFix. CONTREL Manufacturer Information for the user. CONTREL EUROPE nv Incubatie - en innovatiecentrum. Technologiepark 3 B1 (Universiteit Gent), 9052 Gent (Zwijnaarde).

[11] Hargreave M, Morch LS, Andersen KK, Winther JF. Schmiegelow K, Kjaer SK. Maternal use of hormonal contraception and risk of childhood leukaemia - Authors' reply. Maternal use of hormonal contraception and risk of childhood leukaemia. The Lancet Oncology. Correspondence. Volume 19, Issue 12, Pe659, December 01, 2018. DOI: https:// doi.org/10.1016/S1470-2045(18)30849-0.

[12] European Medicines Agency. Science Medicines Health. 29 October 2018. EMA/ PRAC/689235/2018. Pharmacovigilance Risk Assessment Committee (PRAC).

[13] Bhanwra S, Ahluwalia K. The association of oral contraceptive pills with increase in intraocular pressure: Time for pharmacovigilance to step in. Journal of Pharmacology and Pharmacotherapeutics. 6(1):51. January 2015 with 14 Reads. DOI: 10. 4103/0976-500X.149150. Http://www.jpharmacol.com on Wednesday, September 28, 2016, IP: 195.240.6.86.

[14] Morch LS, Skovlund CW, Hannaford PC, Iversen L, Fielding S, Lidegaard O. Contemporary Hormonal Contraception and the Risk of Breast Cancer. $N$ Engl J Med. n engl j med 377; 23 nejm.org December 7, 2017.

[15] Zethraeus N, Dreber A, Ranehill E, Blomberg L, Labrie F, Schoultz B, Johnnesson M, Lindén Hirschberg. A first choice combined oral contraceptive influences general well-being in healthy women. Fertility and Sterility, online 18 April 2017. doi 10.1016/j.fertnstert.2017. 02.120. Available at: ki.se/.../oralcontraceptives-reduce-general-well-being-in healthy-women.

[16] Kraetschmer K. Is the "lege artis" principle obsolete? J Forensic Res. 2013; 4:3.

[17] CTFailure.Table.pdf Available at: www. contraceptivetechnology.org/the-book/take-apeek/contraceptive-efficacy.). (Accessed August 27, 2016). In: Hatcher RA, Trussell J, Nelson AL, Cates W, Kowal D, Policar M. Contraceptive Technology: Twentieth Revised Edition. New York, NY: Ardent Media, 2011. CTFailure. Table.pdf.

[18] World Health Organization (WHO).2017. Effectiveness to prevent pregnancy. Accessed on Nov 20, 2019 at: https://www.who.int/newsroom/fact-sheets/detail/family-planning- 
How Women in Search of Suitable Contraceptive Methods can Remedy the Lack of Counseling and Circumvent Untrustworthy Information Disseminated by Various Media

contraception.

[19] U.S. Food and Drug Association (FDA) Survey of 2013 Food and Drug Administration (FDA) Approved Methods of Birth Control http://
www.fad.gov/ForConsumers/ByAudience/For Women/FreePublications/ ucm313215.htm.) (Accessed January 16, 2017).

Citation: Kurt Kraetschmer MD, PhD. How Women in Search of Suitable Contraceptive Methods can Remedy the Lack of Counseling and Circumvent Untrustworthy Information Disseminated by Various Media. ARC Journal of Gynecology and Obstetrics 2019; 4(3):1-7. DOI: dx.doi.org/10.20431/2455-9792.0403001.

Copyright: (C) 2019 Authors. This is an open-access article distributed under the terms of the Creative Commons Attribution License, which permits unrestricted use, distribution, and reproduction in any medium, provided the original author and source are credited. 